\title{
EL DESPIDO SIN CAUSA, ¿VULNERADOR DE DERECHOS FUNDAMENTALES?
}

\author{
Unfair dismissal, against fundamental rights?
}

\author{
Luis OCAÑa EscolaR*
}

Abogado y profesor asociado de la Universidad de Sevilla

\begin{abstract}
RESUMEN
El despido ha ocupado históricamente un papel central en las relaciones laborales. Se trata de una de las instituciones jurídicas que más reformas legales ha protagonizado y a la vez constituye un aspecto sensible y de conflicto permanente. Podemos advertir dos tendencias enfrentadas. De un lado, encontramos la interpretación neoliberal del mismo, que plantea que su existencia impone una situación de rigidez y propugna en sus formulaciones más radicales el despido libre y gratuito. Se sostiene que el abaratamiento del despido incentiva la creación de empleo y se concibe el mismo como un instrumento de política sociolaboral. De otro lado, existe otra interpretación pone de relevancia la función tuitiva del Derecho del Trabajo y se inclina por establecer requisitos tanto formales como de fondo para que las decisiones extintivas puedan reputarse válidas. Se restringe de esta manera la «licencia para despedir».

El análisis sobre la causalización o no del despido y el establecimiento o no de requisitos formales así como, la fijación de costes — indemnizatorios y por salarios de tramitación — constituyen el objeto del presente estudio a la luz de las últimas reformas legales e interpretaciones jurisprudenciales.

Palabras clave: despido sin causa, derechos fundamentales, causalización del despido.

\section{ABSTRACT}

Dismissal has historically played an important role in labour relations. It is one of the legal institutions which has starred most legal reforms and constitutes a troublesome sensitive aspect. At present, there are two opposed tendencies. On the one hand, the neoliberal intepretation implies that its existence entails rigidness and advocates, in its most radical trends, for free dismissal. It is supported that cheap dismissals foster new employment and dismissal is considered as a sociolaboural political instrument. On the other hand, the othre interpretation highlights the protective character of Employment Law and intends to set formal and fundamental requirements so that they can considered as valid. The "licence to dismiss" is restricted this way.
\end{abstract}

The analysis on the cause of the dismissal and the establishment of formal requirements, as well as costs, including compensations and salaries, are the object of this study taking into account the latest legal reforms and jurisprudential interpretation.

Keywords: unfair dismissal, fundamental rights, cause of the dismissal.

* Correspondencia a: Luis Ocaña Escolar. Calle Otto Engelhardt, número 3-bajo, Sevilla (España). — locana2@us.es — https: // orcid.org/0000-0001-6742-5087

Cómo citar: Ocaña Escolar, Luis. (2021). «El despido sin causa, ¿vulnerador de derechos fundamentales?»; Lan Harremanak, 46, 170-202. (https: //doi.org/10.1387/lan-harremanak.23133)

Recibido: 20 octubre, 2021; aceptado: 13 diciembre, 2021.

ISSN 1575-7048 - elSSN 2444-5819 / (C) 2021 UPV/EHU

(c) (i) Esta obra está bajo una licencia

Creative Commons Atribución 4.0 Internacional 
La racionalidad económica no puede ser el único factor de legitimación de las decisiones empresariales cuando éstas afectan a derechos fundamentales del trabajador como productor y como persona. Sin negar la lógica productiva y la racionalidad económica ni los poderes empresariales sobre las que se sustenta el sistema de libre empresa, la Constitución y los derechos fundamentales debe enmarcar y someter a una revisión crítica de lógica a esos poderes para tener en cuenta los valores constitucionales en torno al trabajo a valorar razones, a ponderar intereses, a justificar decisiones empresariales en terrenos antes propios y de exclusiva titularidad empresarial, de modo que la titularidad empresarial sobre la organización no implica que la sistemática prevalencia de su interés sobre cualquier otro contrapuesto no reconducible al esquema del intercambio económico trabajo-salario.

\section{Profesor Miguel Rodríguez-Piñero y Bravo-Ferrer}

\section{Introducción}

El despido ha ocupado históricamente un papel central en las relaciones laborales. Se trata de una de las instituciones jurídicas que más reformas legales ha protagonizado y a la vez constituye un aspecto sensible y de conflicto permanente. Podemos advertir dos tendencias en torno a la significación del mismo. De un lado, encontramos la interpretación neoliberal del mismo, que plantea que su existencia impone una situación de rigidez y propugna en sus formulaciones más radicales el despido libre y gratuito. Se sostiene desde estas posturas que el abaratamiento del despido incentiva la creación de empleo y se concibe por tanto el mismo como un instrumento de política sociolaboral.

De otro lado, podemos advertir otra interpretación que pone de relevancia la función tuitiva del Derecho del Trabajo y se inclina por establecer requisitos tanto formales como de fondo para que las decisiones extintivas puedan reputarse válidas. Se restringe de esta manera la «licencia para despedir».

La causalización o no del despido, el establecimiento o no de requisitos formales, la fijación de costes —indemnizatorios y por salarios de tramitación-o la cobertura de pagos en caso de insolvencia empresarial han merecido atención por parte de las normas y han configurado diversos regímenes jurídicos caracterizados por sus notas cambiantes.

Se trata, sin duda, de un aspecto muy polémico, de continua actualidad en el panorama informativo y que enciende apasionados debates. Además, desde la perspectiva jurídica se trata de una institución muy conflictiva ${ }^{1}$ y con presencia

${ }^{1}$ La última estadística publicada por el CGPJ evidencia que en 2020 se resolvieron judicialmente 78618 demandas de despido, cuyo montante económico total ascendió a más de 753 millones de euros. En esta estadística no se tienen en cuenta ni los desistimientos, ni las terminaciones "por otras causas» ni las conciliaciones extrajudiciales. 
cotidiana en Juzgados y Tribunales. Prueba de ello es la atención que se le viene prestando desde la doctrina, tanto jurisprudencial como científica.

La estabilidad en el empleo, la causalidad del despido, el efectivo reconocimiento de los derechos fundamentales constitucionales y los regulados en normas internacionales, así como la función tuitiva del Derecho del Trabajo son todos ellos elementos centrales del ámbito laboral que entran en juego a la hora de aproximarnos a la cuestión de los despidos sin causa. Se trata de un asunto que responde a diferentes tradiciones jurídicas y que encuentra diversas regulaciones en atención a diferentes antecedentes históricos y tratamientos legislativos y judiciales.

La falta de unidad de criterios y la existencia de diversas corrientes doctrinales en torno a los despidos sin causa acentúan las discrepancias entre quienes propugnan la estabilidad frente a la flexibilidad y viceversa. De entre las soluciones ofrecidas podremos concluir que estamos ante sistemas caracterizados por la «flexiseguridad» o más bien por la «flexiprecariedad». En todo caso, la destrucción de empleo, es considerada un factor negativo por las implicaciones sociales, económicas y psicológicas que produce. Así, los despidos colectivos gozan de un régimen jurídico diferencia donde la acción de los poderes públicos se caracteriza por los intentos de «salvar» el mayor número posible de empleos. Más particularmente este asunto ha cobrado una muy especial relevancia con la situación de pandemia que aún estamos atravesando y que se inició en marzo de 2020. El colapso de las economías y la recesión económica ha activado mecanismos específicos e inéditos dirigidos a salvaguardar los empleos.

Mientras que el despido disciplinario consiste en una decisión unilateral, por parte del empresario, de extinguir el contrato de trabajo basándose en un incumplimiento contractual grave y culpable por parte del trabajador, de las obligaciones derivadas del contrato de trabajo ${ }^{2}$, el despido improcedente se configura bien como injustificado o incumplidor de los requisitos de forma establecidos por la norma. Ahora bien, ¿es ésta calificación jurídica apta para integrar también los despidos sin alegación de causa e incluso aquellos con alegación de causa falsa? ¿Nos acercamos a al "despido libre pagado» ${ }^{3}$ o nuestro ordenamiento dispone de mecanismos para afrontar específicamente los supuestos de «desistimiento empresarial» 4 ?

El objeto del presente trabajo es el análisis de las líneas jurisprudenciales y doctrinales de los trazos caracterizadores de los despidos sin causa. Para ello, procuraremos sistematizar las principales respuestas que se han ofrecido

\footnotetext{
2 Rubio de Medina, M. ${ }^{a}$ D. (2000) El despido disciplinario, Barcelona: Editorial Bosch.

3 Montoya Melgar, A. (1978) "La estabilidad en el empleo en el Derecho del Trabajo», Revista de Politica Social n.o 118.

4 Luján Alcaraz, J. (2003) «¿Despido improcedente o desistimiento?», Aranzadi Social n.o 3.
} 
al abordar las consecuencias y efectos jurídicos de los denominados despidos sin causa.

A tal fin acudiremos a los criterios tradicionales de enjuiciamiento que concurren en cualquier despido. Estos cinco juicios diferenciados son: el de constitucionalidad, el de formalidad, el de causalidad formal, el de funcionalidad o proporcionalidad y el de antijuridicidad 5 .

En el primero se atiende a si la extinción obedece o no a criterios contrarios a los derechos fundamentales y libertades públicas. En el segundo se estudia si el empresario ha seguido o no los trámites legales. En el tercero se analiza si la causa se adecúa a la legalidad y se acreditan o no los motivos aducidos. En el cuarto, se valora si la causa alegada es o no suficiente para validar la decisión extintiva y en el quinto, se aborda la existencia o no de fraude de ley y/o abuso de derecho.

A tal efecto no podemos olvidar que en nuestra legislación laboral hemos observado importantes cambios legislativos y jurisprudenciales, que han significado la imposición de consecuencias diferentes a supuestos inicialmente análogos. El análisis crítico de los criterios y soluciones ofrecidas es el objeto del presente trabajo. En el mismo, no podemos dejar de abordar que los derechos han de interpretarse conforme a los valores superiores, particularmente los del art. 1.1 CE y la dignidad humana, pero; a la vez, los derechos son valores en sí, más concretamente un orden objetivo de valores (STC 25/81, de 14-7), que se expande a todo el ordenamiento y sirve de parámetro de interpretación del mismo ${ }^{6}$.

La dimensión constitucional y la atención a los derechos fundamentales y su incidencia en el ordenamiento jurídico y en la aplicación e interpretación del mismo constituyen, sin duda, el eje del presente estudio.

\section{El principio de causalidad en el despido}

Debemos comenzar destacando que no es posible encontrar ninguna definición legal del despido, por lo que debemos acudir a la doctrina científica. Así, Bayón lo define como «el acto jurídico unilateral, expreso y recepticio por el que un empresario pone fin a la vigencia del contrato de trabajo que le ligaba con un trabajador» ${ }^{7}$, mientras Montoya Melgar concreta que es un «acto unilateral,

\footnotetext{
5 Falguera, M. A. (2016) El control judicial del despido colectivo, Albacete: Bomarzo.

${ }^{6}$ Preciado, C. H. (2016) Interpretación de los derechos humanos y los derechos fundamentales, Cizur Menor: Aranzadi.

7 Bayón Chacón, G. (1969) El despido, concepto y clases» en AA.VV.: Dieciséis lecciones sobre causas de despido. Madrid: Universidad de Madrid. Facultad de Derecho. Sección de Publicaciones e Intercambio.
} 
constitutivo y recepticio por el cual el empresario procede a la extinción de la relación jurídica de trabajo» ${ }^{8}$.

Así, las causas extintivas de las relaciones laborales se suelen clasificar en tres grupos:

a) las causas provocadas por la voluntad de una de las partes.

b) las causas provocadas por la voluntad de ambas partes.

c) las causas ajenas a la voluntad de las partes.

En el presente trabajo, nos centraremos exclusivamente en el primero de los supuestos: despidos que responden a la exclusiva voluntad patronal. Y debemos añadir un elemento adicional, los despidos sin causa se alejan de los requisitos exigidos por el ordenamiento por cuanto que no ofrecen al trabajador ninguna explicación de las causas en virtud de las cuales se adopta tal decisión. ¿Estamos ante un incumplimiento grave y culpable del empresario? En cualquier caso, estamos ante una decisión que produce efectos directos e inmediatos sobre la relación laboral y constituye una manifestación del poder del empresario.

Se produce una indiscutida tensión del principio de causalidad que rige en nuestro ordenamiento y que viene a proteger el derecho a no ser despedido salvo por una justa causa lo que apuesta por la subsistencia del contrato de trabajo y por el reconocimiento de la dimensión axiológica de las causas justas. Además, el reconocimiento de la causalidad incide de lleno en la seguridad jurídica.

La causalidad puede ser vista como una manifestación del principio de estabilidad del empleo que preside las relaciones laborales ${ }^{9}$. Es una opción legislativa optar por el despido libre o establecer un sistema de despido causal ${ }^{10}$. En los últimos tiempos, se observa una decidida tendencia a la descausalización progresiva del despido, tan acusada que podríamos afirmar que estamos ante un sistema de despido libre indemnizado o cuando menos, ante un sistema de despido causal muy atenuado. De hecho, nuestro modelo se caracteriza por estos tres rasgos en materia de despido: descausalizado, desjudicializado «relativamente» $\mathrm{o}$ "en parte», y con coste económico cierto ${ }^{11}$.

${ }^{8}$ Montoya Melgar, A. (2006) Derecho del Trabajo, Madrid: Tecnos.

${ }^{9}$ Así Montoya Melgar (op. cit.) dice que: «la estabilidad en el empleo es un principio acogido decididamente por nuestro Derecho del Trabajo. La propia Constitución, aunque a diferencia de otras leyes fundamentales no consagra expresamente ese principio, lo recoge de modo implícito al acoger el derecho al trabajo (art. 5.1); un derecho éste que si no puede esgrimirse en demanda de un efectivo puesto de trabajo sí puede invocarse como fundamento de la presunción a favor de la duración indefinida del contrato de trabajo y de la ilicitud de las extinciones contractuales sin causa justa».

${ }^{10}$ Rige este sistema causal en Japón, Canadá, Gran Bretaña y todos los estados de la Unión Europea.

11 Lahera, J. (2009) «Las paradojas del despido libre pagado (Sentencia del Tribunal Supremo de 22 de enero de 2008, recurso 1689/2007)», en Relaciones Laborales, número 2. 
La existencia del principio de causalidad conecta directamente con las cuatro tesis de la teoría de la democracia constitucional de Ferrajoli ${ }^{12}$.

La primera tesis establece la diferencia radical que se aprecia entre derechos fundamentales y derechos patrimoniales. Identifica cuatro claras diferencias estructurales:

1. Mientras que los derechos fundamentales son universales (omnium), los derechos patrimoniales son derechos singulares (singuli).

2. Los derechos fundamentales son indisponibles —activa y pasivamente-, inalienables, inviolables, intransigibles y personalísimos. Por su parte, los derechos patrimoniales son, por su naturaleza, negociables y alienables. Son susceptibles de ser acumulados mientas que los fundamentales permanecen invariables. Hay una notoria diferencia que se sustancia en la posibilidad de ser bien objeto de cambio en la esfera del mercado bien expropiado por causas de utilidad pública.

3. Los derechos fundamentales son normas y los derechos patrimoniales son predispuestos por normas. Los primeros inmediatamente disponen las situaciones expresadas a diferencia de los segundos, que predisponen situaciones jurídicas como efectos de los actos previstos por ellas.

4. Los derechos patrimoniales son horizontales y los derechos fundamentales son verticales. Los primeros generan relaciones intersubjetivas que afectan a la esfera privada y los segundos constituyen situaciones públicas cuya observancia es condición de legitimidad de los poderes públicos.

La segunda tesis explica que los derechos fundamentales conforman el fundamento de la igualdad jurídica y sustentan la dimensión sustancial de la democracia. Tan es así que el pacto constitucional otorga el carácter de fundamental como técnica de tutela a fin de garantizar una necesidad o interés que se sustrae tanto al mercado como a las decisiones de la mayoría. Los derechos fundamentales están "por encima" de las mayorías y operan como fuentes de invalidación y de deslegitimación más que de legitimación. Se trata de derechos orientados hacia y, si es necesario, contra el Estado, esto es, contra los poderes públicos, aunque sean democráticos o de mayoría.

La tercera tesis se refiere a la naturaleza supranacional de gran parte de los derechos fundamentales. En realidad, se trata de derechos supraestatales a los que los Estados están vinculados y subordinados también en el plano del derecho internacional. Opina Ferrajoli que a largo plazo la antinomia entre igualdad

12 Expuesta por Ferrajoli, L. (2019) Derechos y garantías, Madrid: Trotta. 
y ciudadanía tendrá que resolverse con la superación de la ciudadanía, la definitiva desnacionalización de los derechos fundamentales y la correlativa desestatalización de las nacionalidades. Y ello es fruto del profundo nexo que existe entre democracia a igualdad. De lo contrario y en caso de que prevalezca la desigualdad, aflorará el racismo y la construcción de la imagen de los otros como desiguales - inferiores en el plano antropológico- precisamente por ser inferiores en el plano jurídico.

Y la cuarta tesis atiende a las relaciones entre derechos y garantías. Diferencia entre aquellas que consisten en expectativas negativas o positivas a las que corresponden obligaciones de prestación o prohibiciones de lesión (garantías primarias) y las obligaciones de reparar o sancionar judicialmente las lesiones de los derechos, esto es las violaciones de las anteriores garantías (garantías secundarias). Parte de la idea kelseniana de que un derecho no garantizado no es un verdadero derecho y concluye que los obstáculos a la hora de la plena efectividad de los derechos resultan ser de naturaleza política.

\section{El principio de buena fe en las relaciones laborales}

El principio de buena fe es una institución central en el ámbito del Derecho del Trabajo, si bien se trata de un concepto jurídico indeterminado, cuya aplicación requiere en la mayoría de casos del auxilio jurisdiccional ${ }^{13}$.

De acuerdo a la jurisprudencia del TS, la buena fe

constituye un modelo de tipicidad de conducta exigible o, mejor aún, un principio general del derecho que impone un comportamiento arreglado a valoraciones éticas, que condiciona y limita por ello el ejercicio de los derechos subjetivos (arts. 7.1 y $1258 \mathrm{del} \mathrm{CCl}$ ), con lo que el principio de convierte en un criterio de valoración de conductas con el que deben cumplirse las obligaciones, y que se traduce en directivas equivalentes a lealtad, honorabilidad, probidad y confianza» (STS 4-3-1991).

Más recientemente se ha pronunciado el TSJ de Castilla y León - Sala de Valladolid- en su sentencia de 14-5-2003 diciendo sobre la buena fe que:

constituye un valor medular de la relación contractual, incorporando un componente ético mínimo que se reconoce, en la observancia de aquella conducta exigible según los parámetros sociológicos imperantes, en orden al cumplimiento leal y diligente de las obligaciones voluntariamente asumidas, sin desviaciones objetiva y razonablemente idóneas para hacer desaparecer la confianza ajena.

13 Del Rey, S. (1995). «Derechos fundamentales de la persona y contrato de trabajo: notas para una teoría general», Relaciones Laborales: revista crítica de teoría y práctica, número 186, tomo I. 
Estamos, por tanto, ante un valor directamente conectado a lo considerado ético, apreciable en las conductas humanas y que responde al cumplimiento de las obligaciones contractuales respondiendo a unos determinados estándares sociales que generan confianza en la comunidad.

La STC 90/1999 dice al respecto que la buena fe en modo alguno puede suponer un genérico deber de lealtad a la empresa que fuera omnicomprensivo de una situación de sujeción al interés empresarial» y más concretamente la STC $192 / 2003$ ha razonado que «la buena fe ha sido vista como un concepto abierto al mundo de las valoraciones sociales», que la introducción de este concepto "ha buscado la incorporación al ordenamiento jurídico de un factor de flexibilización, capaz de adaptar la normas a las nuevas circunstancias y valores de la sociedad» y que «a la hora de decidir sobre el contenido de mandatos como la buena fe, ha de partirse, en primer término, de la totalidad de las representaciones de valor fijadas en la Constitución que la sociedad ha alcanzado en un determinado momento de su desarrollo cultural» y que «lo que en cada caso se decida que corresponde a la buena fe no podrá estar en desacuerdo con dichos mandatos constitucionales».

En el mismo sentido por parte de la doctrina se afirma que

la transgresión de la buena fe se ha convertido en un tipo casi perfectamente elástico, susceptible en la práctica de acoger cualquier comportamiento del trabajador en el que se aprecie un incumplimiento de sus deberes como sujeto del contrato de trabajo ${ }^{14}$.

La doctrina especializada distingue tres tipos de conductas en que puede concurrir la transgresión de la buena fe contractual por parte del trabajador: las singularizadas por la causación de dańo a la empresa, las destacadas por la desviación de poder y, finalmente, las caracterizadas por la presencia intensa de la nota de engaño u ocultamiento ${ }^{15}$. Ahora bien, se echa en falta tanto la construcción jurisprudencial como doctrinal de lo que debe entenderse por buena fe patronal ${ }^{16}$. Y

${ }^{14}$ Rodríguez Sañudo, F. (1990). «La transgresión de la buena fe contractual como causa de despido", en Cuestiones Actuales de Derecho del Trabajo. Estudios ofrecidos por los catedráticos españoles de Derecho del Trabajo al profesor Manuel Alonso Olea, Madrid: Ministerio de Trabajo y Seguridad Social.

15 Gómez Abelleria, F. J. (2009). La causalidad del despido disciplinario, Cizur Menor: CivitasThomson Reuters.

16 Así se reconoce expresamente por García Viña, que afirma: «Quizás en el aspecto que más novedad podía suponer, en cuanto a la función normativa de la buena fe, si asume tareas integrativas, no está nada desarrollado. Sin embargo, es cierto que en materia de Derecho del Trabajo esta función no debería tener tanta relevancia como en el resto de contratos ya que existe una fuente de regulación tan importante como es la negociación colectiva, de manera que las lagunas tendrían que ser menores. En todo caso, y previendo esta posibilidad, si aun así existieran cuestiones no reguladas por las partes, la buena fe podría integrar dichas cláusulas. En todo caso, se debe tener en cuenta que no existe ninguna resolución judicial que aborde este tema, lo que significa que, o bien no existen discrepancias sobre el mismo, o, quizás es más acertado decir, que sencillamente es una materia que escasamente se plantea en las relaciones laborales" (García Viña, J. (2000) El principio general de la buena fe en cl contrato de trabajo, Tesis Doctoral, Barcelona: Universidad de Barcelona). 
de igual manera que este principio no aparezca consagrado o reconocido en ninguna parte de nuestra $\mathrm{CE}^{17}$. Se le suelen atribuir dos límites: uno exógeno y otro endógeno. El primero hace referencia a los márgenes mínimos de convivencia en la paz social y la plenitud del resto de derechos fundamentales mientras que el segundo viene impuesto por la esencia del concepto mismo del derecho, ontológicamente incompatible con el abuso, el daño de los bienes sociales o el fraude de los fines del ordenamiento.

Ahora bien, conviene destacar, a este respecto el valor normativo y no meramente programático de valores y principios, que vinculan a todos los Poderes Públicos y son origen inmediato de derechos y obligaciones ${ }^{18}$. Esto debe ser puesto en consonancia con la afirmación constitucional del artículo 9.2 que conlleva importantes repercusiones en el ámbito interpretativo de las normas procesales laborales, tales como la inversión del onus probandi o la discriminación inversa.

Para completar la perspectiva jurídica sobre el principio de buena fe, debemos, pues acudir a la jurisprudencia constitucional, que en su STC 192/2003 establece:

La aplicación judicial del Derecho es, como toda interpretación, realización de valor, esto es, una elección entre varias valoraciones posibles hacia cuyos principios aquélla se orienta. La buena fe ha sido vista como un concepto abierto al mundo de las valoraciones sociales. La introducción de la referida categoría ha buscado la incorporación al ordenamiento jurídico de un factor de flexibilización, capaz de adaptar la norma a las nuevas circunstancias y valores de la sociedad. Por ello, a la hora de decidir sobre el contenido de mandatos como la buena fe, ha de partirse, en primer término, de la totalidad de las representaciones de valor fijadas en la Constitución que la sociedad ha alcanzado en un determinado momento de su desarrollo cultural. En consecuencia, lo que en cada caso se decida que corresponde a la buena fe no podrá estar en desacuerdo con dichos mandatos constitucionales, toda vez que la Constitución es la norma suprema de todo el ordenamiento jurídico a la que se debe acomodar cualquier otra, así como la interpretación y aplicación de la legalidad por parte de los órganos judiciales.

La causa del despido que sirve de base a la presente controversia encaja, en este caso, en el supuesto previsto en el art. 54.2 d) LET, donde se recoge como tal la transgresión de la buena fe contractual, por lo que el control que, dentro de nuestro canon de enjuiciamiento, nos corresponde, debe concentrarse en la valoración de si los razonamientos utilizados por las resoluciones impugnadas para fundamentar la aplicación de la cláusula general de la buena fe en un supuesto de despido disciplinario se adecuan a los valores y principios constitucionalmente definidos. Tal exigencia aparece reforzada por el hecho de que tanto

\footnotetext{
17 Moreno García, A. (1993). «Buena fe y derechos fundamentales en la jurisprudencia del Tribunal Constitucional», en Revista Española de Derecho Constitucional, número 38.

18 Así lo establece la STC 31/1994, de 31-1.
} 
exigencias constitucionales, como compromisos internacionales, hacen que rija entre nosotros el principio general de la limitación legal del despido, así como su sujeción para su licitud a condiciones de fondo y de forma. Ello no quiere decir que, como poder empresarial, la facultad de despido no se enmarque dentro de los poderes que el ordenamiento concede al empresario para la gestión de su empresa y que, por ello, su regulación no haya de tener en cuenta también las exigencias derivadas del reconocimiento constitucional de la libertad de empresa y de la defensa de la productividad, pero lo que resulta claro es que no puede deducirse de esa libertad de empresa ni una absoluta libertad contractual, ni tampoco un principio de libertad ad nutum de despido, dada la necesaria concordancia que debe establecerse entre los arts. 35.1 y $38 \mathrm{CE}$ y, sobre todo, el principio de Estado social y democrático de Derecho. No debe olvidarse que hemos venido señalando desde nuestra STC 22/1981, de 2-7, FJ 8, que, en su vertiente individual, el derecho al trabajo (art. 35.1 CE) se concreta en el «derecho a la continuidad o estabilidad en el empleo, es decir, en el derecho a no ser despedido sin justa causa».

Esta regla de la buena fe es plenamente coherente con lo que dispone el CC en su artículo 1.256, que establece: «la validez y el cumplimiento de los contratos no pueden dejarse al arbitrio de uno de los contratantes».

En el caso del abandono, el negocio implica un incumplimiento de un negocio previo y es, por tanto, un acto antijurídico ante el que la norma tiene que reaccionar. El régimen de protección puede ser de carácter sustantivo y/o procesal.

$\mathrm{Y}$ en torno a la reparación del daño, Zanonni nos indica que existen dos maneras de repararse:

un modo de hacerlo es a través de lo que se denomina reparación natural o in natura que consiste en la reintegración en forma específica, o reparación en especie. Implica literalmente volver las cosas al estado que tendrían si no hubiera ocurrido el hecho dañoso. (...) El otro modo de reparar el daño es la llamada reparación por equivalente o, propiamente, indemnización mediante la cual aunque no se repone o reintegre en forma específica el bien dañado, se compensa o resarce el menoscabo patrimonial sufrido en razón del daño: se tiende, de esta manera, a restablecer el equilibrio patrimonial en función del valor que representa el perjuicio».

\section{El employment at-will y el despido libre sin causa ${ }^{19}$}

Podemos traducir la expresión «employment at-will» como «empleo a voluntad de las partes». Se trata de una institución paradigmática de la flexibili-

19 Seguimos en este epígrafe la completa monografía de Cano y Galán, Y. (2000): El despido libre y sus limites en el derecho norteamericano, Madrid: Consejo Económico y Social. 
dad en el ámbito laboral que hace descansar el mantenimiento del empleo en la mera voluntad de las partes. Se parte de la concepción de que la relación laboral - por el mero hecho de existir - se concierta por tiempo indefinido y puede terminarse en cualquier momento, por cualquier motivo y por cualquiera de las partes.

La vigencia de la regla del «employment at-will» en el derecho norteamericano es incuestionable. Y la más clara prueba de ello podemos encontrarla en el rotundo fracaso de la "Model Employment Termination Act» en 1991, proposición de ley modelo para los cincuenta estados cuya falta de implantación en ninguno de ellos denotó la vigencia del modelo «at-will». Se trata de una institución única en los denominados países industrializados y que viene rigiendo en Estados Unidos desde hace más de un siglo. Su explicación económica tiene que ver con la reducción de los costes marginales en cualquier actividad económica en condiciones de cambio tecnológico y empresarial, lo que facilita la adaptación de las empresas a las oscilaciones de los mercados.

Ahora bien, la regla está muy matizada por los siguientes factores:

- Es una regla que se aplica en ausencia de otra regla, por lo que tiene carácter subsidiario.

- No se aplica en las relaciones laborales concertadas por tiempo determinado.

- Tampoco se aplica a los trabajadores sindicados y/o cubiertos por la negociación colectiva.

—Existen las llamadas «exception-riddled at-will rule», excepciones generadas en virtud de la jurisprudencia. Se manifiesta así en todo su esplendor el sistema jurídico anglosajón basado en los "precedentes», que en este caso se ve reforzado por la incertidumbre que genera el carácter no tasado de las indemnizaciones.

Debemos destacar pues, que la figura del «employment at-will» opera sobre la entrada y salida del mercado laboral. En nuestro modelo, el origen del contrato de trabajo puede ser identificado en cuatro construcciones jurídicas que corresponden, a su vez, a tres diferentes tradiciones jurídicas diferentes: el arrendamiento de servicios que introdujo el Code Civil francés de 1804, el contrato fiduciario de servicios alemán, el contrato para servir inglés y el contrato de mandato mercantil, construcción común a varios países.

Y por cuanto respecta a la salida del mercado laboral, es notorio que la decisión inmotivada del empleador por el despido origina verdaderas lesiones a la dignidad de los trabajadores afectando, directamente, su desarrollo personal y profesional. En este sentido, la manifestación o expresión de las causas que justifican el despido constituye un bien humano jurídicamente protegible, un derecho fundamental de los trabajadores. 
Como derecho fundamental, la debida motivación del despido posee una doble dimensión individual y objetiva o institucional. La dimensión individual del derecho a un despido justificado permite a los trabajadores exigir que sus empleadores expresen los motivos que fundamentan su decisión, con el fin de identificar si los mismos se ajustan, material y formalmente, a derecho. De esta manera se garantiza que la decisión del empleador no constituye un abuso, sino que es producto de un análisis detallado y razonado, que justifica la decisión tomada. Por su parte, en su dimensión institucional, la debida motivación de la decisión del empleador por el despido sirven como medio de referencia para tener constancia de que la actuación realizada por la empleadora no constituye una acción arbitraria disminuyendo, con ello, la litigiosidad de esta difícil decisión y contribuyendo a la economía procesal, lo que beneficia a toda la comunidad política.

Ahora bien, la no motivación del despido impide la reacción procesal del trabajador frente a la extinción de la relación laboral por parte del empresario, siendo este uno de los aspectos básicos del derecho del trabajo en relación directa con el derecho a la tutela judicial efectiva, en tanto no se le ha informado al trabajador de las razones por las cuales tal extinción se ha producido y, en consecuencia, se encuentra imposibilitado de defenderse adecuadamente en los Tribunales.

En todo caso, sí que se constata un claro acercamiento al modelo norteamericano por cuanto que venimos observando una acusada tendencia a la reducción de los costes en casos de despido improcedente.

\section{La evolución doctrinal sobre los despidos sin causa}

La construcción jurisprudencial realizada en torno a la figura de los despidos sin causa arranca, a su vez, de otra construcción jurisprudencial realizada por el Tribunal Constitucional: el despido radicalmente nulo. Fue con la STC 38/1981, cuando el Alto Tribunal afirmó:

Un principio de justicia, que opera en el tratamiento de las reglas de la prueba, apoya la conclusión de que asuma el empresario la carga de probar los hechos generadores de la extinción de la relación laboral, bien constituyan causa legítima subsumible en alguna de las de ruptura unilateral de aquélla, a impulso del empresario, bien sin legitimar el despido por causas excluyentes de su procedencia o por incurrir en nulidad, se presenten razonablemente como ajenos a todo propósito discriminatorio atentatorio a un derecho constitucional.(...) La cuestión para nosotros es reconocer el derecho o libertad pública y adoptar, dentro de lo previsto en el art. 55.1 de la LOTC, las medidas precisas para restablecer a los demandantes en la integridad de su derecho. Pues bien, se cumple dicho objetivo, afirmando que la nulidad es radical, y, 
por ello, comporta necesariamente la readmisión, excluyéndose toda facultad de opción ejercitable por el empresario, pues los efectos que se anudan a tal nulidad reclaman la reintegración de los trabajadores en su puesto con el pago de los salarios y el mantenimiento de sus derechos adquiridos. La naturaleza de la obligación de readmisión y los medios de coercibilidad de la misma y el tratamiento, en su caso, de los medios sustitutorios de la restitución in natura, son, por lo demás, materias que justificarán pronunciamientos ejecutorios en su tiempo - y por el cauce previsto para la ejecución-, más que no reclaman ahora pronunciamientos previsores ante la eventualidad de obstáculos en la ejecución.

A tal efecto, resulta especialmente relevante detenernos en los elementos considerados por el TC en su análisis de los despidos radicalmente nulos, a saber:

Corresponde al empresario la carga de la prueba en los casos de extinción de la relación laboral motivada por su voluntad.

Se asigna a esa tarea probatoria, el acreditar que no concurre un móvil discriminatorio ni se contravenga mediante la decisión extintiva algún derecho constitucional.

Cuando la nulidad es radical, opera la previsión de la LOTC $^{20}$ y en consecuencia la tutela puede desplegar los siguientes efectos: el declarativo, la restitución o restablecimiento, el inhibitorio y el indemnizatorio.

Tales efectos persiguen la plena efectividad del derecho fundamental vulnerado y se justifican con arreglo a que no despliegue ningún efecto el acto declarado nulo por resultar contrario a los valores y derechos que ostentan el mayor grado de protección jurídica de que disponemos en el ordenamiento jurídico.

${ }^{20}$ El tenor literal del artículo 55 LOTC es el siguiente:

Artículo cincuenta y cinco

Uno. La sentencia que otorgue el amparo contendrá alguno o algunos de los pronunciamientos siguientes:

a) Declaración de nulidad de la decisión, acto o resolución que hayan impedido el pleno ejercicio de los derechos o libertades protegidos, con determinación, en su caso, de la extensión de sus efectos.

b) Reconocimiento del derecho o libertad pública, de conformidad con su contenido constitucionalmente declarado.

c) Restablecimiento del recurrente en la integridad de su derecho o libertad con la adopción de las medidas apropiadas, en su caso, para su conservación.

Dos. En el supuesto de que el recurso de amparo debiera ser estimado porque, a juicio de la Sala o, en su caso, la Sección, la ley aplicada lesione derechos fundamentales o libertades públicas, se elevará la cuestión al Pleno con suspensión del plazo para dictar sentencia, de conformidad con lo prevenido en los artículos 35 y siguientes». 
Nos encontramos, pues, ante una reacción jurídica proporcional a la gravedad del comportamiento merecedor de la corrección. En palabras del TS — sentencia de 23-11-1988-, ello

acredita una conducta en la demandada tendente a evitar que las leyes se apliquen de acuerdo con la finalidad que les dio vida, con la consiguiente producción de unos efectos no queridos por el ordenamiento jurídico al ser contrarios a la realización de la justicia, al sentido ético y contenido objetivo de la norma legal; debiendo reaccionar el ordenamiento jurídico en casos como el enjuiciado, en los que se encuentra probada una confabulación para obtener un resultado contrario a derecho, que pone al servicio de esta actividad antijurídica una serie de apariencias y formalidades, con objeto de describir cuál sea la realidad que subyace en dichas conductas. Por lo expuesto, en el presente caso no pueden entrar en juego los preceptos estatutarios aplicados por el Magistrado de instancia, al no existir causa alguna para el despido, sino una apariencia, ficticiamente creada por la empresa, de la existencia de determinadas faltas de asistencia al trabajo del trabajador y, en su virtud, procede declarar nulo «in radice» el despido, al no tener encuadre alguno en el Estatuto de los Trabajadores.

Pues bien, siguiendo esta línea, la Sentencia del TS de 20-2-1989 estableció que:

la nulidad radical del despido — construcción jurisprudencial, pues tal tipo no aparece en el ET - se dará en supuestos en que exista infracción a un derecho constitucionalmente reconocido al trabajador — normalmente suele tratarse de despido discriminatorio por motivos sindicales - o bien por entrańar un fraude claro y patente sin que exista base alguna para imputación que se considere totalmente inaceptable y violadora del principio de buena fe que ha de presidir la relación jurídica y con mayor motivo la laboral (artículo 1258 CC y artículo 20.2 ET).

De este modo fue la propia jurisprudencia del TS la que vino a ampliar las causas que determinaban la "nulidad radical», que no se limitaba exclusivamente a las vulneraciones de los derechos constitucionales, sino que también alcanzaban los supuestos de violación del principio de buena fe, exigiendo eso sí no una mera deficiencia en la carta de despido sino un "plus» de anticonstitucionalidad.

Profundizando en esta idea, el propio TS decía en su sentencia de 21-31989 lo siguiente:

la calificación del despido como radicalmente nulo, aun huérfana en el ordenamiento positivo de previsión expresa, constituye no obstante la respuesta judicial procedente, con consecuencias en orden a sentido de la condena que ante su presencia corresponde, frente a supuestos en los que la unilateral resolución decidida por la empresa obedeciera a factores discriminatorios, manifestando desconocimiento o violación de derechos de la persona que, por garantizar el área de su propia realidad individual y social, han de ser considerados como intangibles . (...) la nulidad radical no sólo viene impuesta cuando el acto del despido manifiesta desigualdad discriminatoria, sino también si resultan perjudicados otros derechos fundamentales y libertades públicas del trabajador afectado. 
La evolución de dos corrientes jurisprudenciales enfrentadas se evidencia a la perfección con la Sentencia del Tribunal Superior de Cataluña 7077/2004, de 15-10. La corriente mayoritaria expresaba:

Frente a la sentencia de instancia, estimatoria en parte de la demanda inicial de despido disciplinario, al declarar la improcedencia del mismo, se alza en suplicación la parte actora, que peticiona su nulidad por discriminación o vulneración de derechos fundamentales, articulando su recurso por la única vía del apartado c) del artículo 191 de la Ley de Procedimiento Laboral, que ha sido impugnado por la parte demandada. El único motivo del recurso denuncia la infracción de los artículos 55.4.2.c) y 17 del Estatuto de los Trabajadores y artículo 43.1 de la Constitución, interpretados por la sentencia de esta Sala de 26 de septiembre de 2002. Alega la recurrente que en el presente caso se despidió a una trabajadora que se hallaba de baja, iniciada por accidente de trabajo, sin explicación alguna, limitándose a invocar un apartado del precepto que establece las causas de despido disciplinario, concretamente la disminución continuada y voluntaria del rendimiento, y ante la imputación en la demanda de violación de derechos fundamentales, sin proponer prueba alguna, se limita a señalar que la decisión del despido se tomó antes de que la trabajadora iniciara la baja, nada menos que 9 meses antes, entendiendo que es evidente la inexistencia de causa real para el despido y debería acarrear la nulidad del mismo por inexistencia de causa, insistiendo en que no es posible invocar una causa de despido disciplinario y en el mismo momento reconocer su improcedencia, y que esta conducta constituye una burla del ordenamiento jurídico y un palmario fraude de ley. Debe matizarse que la nulidad radical del despido perdió su sentido tras la promulgación de la nueva Ley de Procedimiento Laboral y la jurisprudencia puso de manifiesto que las causas de nulidad del despido eran las enumeradas en el citado artículo 108.2 y ninguna otra, entendiéndose incluso que el fraude de ley tampoco constituía razón para calificar como nulo un despido. Más restrictivo aún ha sido el artículo 55.5 del Estatuto de los Trabajadores en la redacción dada por la Ley 11/94 así como el nuevo artículo 108.2 de la Ley de Procedimiento Laboral, no ya respeto a la nulidad radical, que el Texto Procesal de 1.990 vació de contenido y razón de ser, sino respeto a la nulidad simple. Esta última solamente se puede apreciar cuando la decisión empresarial sea discriminatoria o vulnere derechos fundamentales y libertades públicas del trabajador.

Se infiere, por tanto, que, al entender de la posición mayoritaria, no se produce ni discriminación ni vulneración de derechos fundamentales o libertades públicas del trabajador cuando el despido carece de causa o cuando la causa no es una de las expresamente invocadas por la legislación ordinaria. Es una interpretación restrictiva del alcance de los derechos fundamentales y de su papel informador del ordenamiento jurídico, así como de las relaciones entre particulares.

Se trata de una aceptación por parte del ordenamiento y de la jurisprudencia del fraude de ley como causa de improcedencia.

Por su parte, el voto particular — minoritario- discrepaba de la posición mayoritaria en los siguientes términos: 
Cabe recordar, en este sentido, que en nuestro ordenamiento el despido es causal. Así se dimana de lo preceptuado en el art. 4 del Convenio 158 de la OIT, subscrito por el Estado español en fecha 26 de abril de 1985 y conforme al cual «No se pondrá término a la relación de trabajo de un trabajador a menos que exista para ello una causa justificada relacionada con su capacidad o su conducta o basada en las necesidades de funcionamiento de la empresa, establecimiento o servicio».

El mentado texto comporta — como ha puesto reiteradamente de manifiesto la doctrina - que en nuestro modelo de relaciones laborales - por aplicación del principio de jerarquía normativa que contempla el art. $96 \mathrm{CE}$ en relación a la Ley - no tenga cabida la figura del desistimiento por parte del empleador, a diferencia de otros sistemas jurídicos comparados — más o menos cercanosque sí reconocen dicha figura con mayor o menor amplitud y que, precisamente por ello, no han suscrito el mentado convenio.

Es más, la propia doctrina del Tribunal Constitucional viene poniendo en tela de juicio que — más allá de las obligaciones internacionales - la extinción del contrato de causa en nuestro sistema constitucional. Como se señala en la reciente STC 192/2003, de 27-10:

tanto exigencias constitucionales, como compromisos internacionales, hacen que rija entre nosotros el principio general de la limitación legal del despido, así como su sujeción para su licitud a condiciones de fondo y de forma. Ello no quiere decir que, como poder empresarial, la facultad de despido no se enmarque dentro de los poderes que el ordenamiento concede al empresario para la gestión de su empresa y que, por ello, su regulación no haya de tener en cuenta también las exigencias derivadas del reconocimiento constitucional de la libertad de empresa y de la defensa de la productividad, pero lo que resulta claro es que no puede deducirse de esa libertad de empresa ni una absoluta libertad contractual, ni tampoco un principio de libertad ad nutum de despido, dada la necesaria concordancia que debe establecerse entre los arts. 35.1 y $38 \mathrm{CE}$ y, sobre todo, el principio de Estado social y democrático de Derecho. No debe olvidarse que hemos venido señalando desde nuestra STC 22/1981, de 2-7, FJ 8, que, en su vertiente individual, el derecho al trabajo (art. 35.1 CE) se concreta en el «derecho a la continuidad o estabilidad en el empleo, es decir, en el derecho a no ser despedido sin justa causa.

Obsérvese, sin embargo, que dicho corolario jurídico es postulable de la figura de despido, no del desistimiento. Es obvio, en ese sentido, que en un proceso de despido los órganos judiciales ad hoc realizan, en realidad, un cuádruple control, a saber: a) el de constitucionalidad — si se invoca vulneración de derechos fundamentales o derechos asimilados a los mismos-; b) el de formalidad — valorando el cumplimiento de los requisitos legales_; c) el de causalidad —analizando si existe causa suficiente-; y d) el de proporcionalidad, determinando si la conducta o situación que se imputa o formula es suficiente. 
Es cierto que la doctrina unificada ha limitado el control de causalidad a un aspecto meramente formal. Ahora bien, resulta prácticamente imposible, sin embargo, que pueda un juzgador realizar tal valoración si el despido es escrito y no existe ninguna causa justificativa que lo motive y conste. Por tanto, si no existe justificación - y el despido no es verbal o tácito- no nos hallaremos ante un despido, sino ante un desistimiento, con todos sus efectos.

Para tales supuestos, los efectos no pueden ser otros que los previstos en el art. 6.3 del CC. Y ello porque no estaremos entonces ante un mero fraude de ley sino ante un acto contrario a las normas imperativas - el 4 del Convenio 158 OIT, de directa aplicación ex art. 96.1 CE—, lo que debe comportar su nulidad de pleno derecho. La antijuridicidad merece tal reproche.

En coherencia con la anterior, el propio TSJ de Cataluña había dictado la sentencia 917/2004 donde afirmaba:

la especial clase de despido nulo es una figura excepcional y extraordinaria cuya declaración de existencia exige la concurrencia de elevadas dosis de arbitrariedad y capricho en la actuación del empresario sin que sea suficiente el que la misma sea ilícita o contraria a la Ley - porque tanto el despido nulo como el improcedente implican contradicción o incumplimiento de la normativa legal — sino que esa ilegalidad ha de ser intensa y superlativa resultando con ella vulnerados los más elementales principios del ordenamiento jurídico laboral que, no constando en el supuesto enjuiciado conlleva a la obligada desestimación del recurso de suplicación.

Ahora bien, la calificación de nulidad en los despidos fraudulentos es una opción descartada por la doctrina jurisprudencial desde hace algunos años. Resulta a tal efecto paradigmática la STS 5-5-2015, rec. 2659/2013).

Esta línea jurisprudencial sobre la carencia de «apoyo o refrendo legal» de la nulidad del despido fraudulento se inicia en STS 2-11-1993 (rec. 3669/1992), y continúa en STS 19-1-1994 (rec. 3400/1992), STS 23-5-1996 (rec. 2369/1995) y 30-12-1997 (rec. 1649/1997). Puede observarse a tal efecto la doctrina del TS con la siguiente consideración «Cuando no hay causa legal para la extinción del contrato de trabajo y la causa real no se encuentra entre las tipificadas como determinantes de la nulidad del despido — concluye STS 29-2-2001la calificación aplicable es la de improcedencia» del despido, y no la de nulidad del mismo. En esta línea también se manifiestan las sentencias de 22-1-2008 (rec. 3995/2006), 27-1-2009 (rec. 602/2008) y 22-11-2007 (rec. 3907/2006).

Y de las más recientes podemos destacar la STS 29-11-2017, que dispone:

Cuando no hay causa legal para la extinción del contrato de trabajo y la causa real no se encuentra entre las tipificadas como determinantes de la nulidad del despido - concluye STS 29-2-2001- la calificación aplicable es la de improcedencia del despido, y no la de nulidad del mismo. 
La nulidad del despido se configura en atención a una lista cerrada de supuestos tasados (numerus clausus). Fuera de estas previsiones, todos aquellos ceses en que pueda incurrir la parte empleadora merecerán la calificación de procedentes o improcedentes.

Subyace bajo esta concepción la idea de que todo despido responde a una causa y que tal causa es la que viene a motivar el interés en disolver el vínculo jurídico. Se acentúa así, la más amplia manifestación del principio de libertad empresarial, que alcanzaría incluso a la no alegación de causa alguna o a la alegación de causa falsa.

Es un claro exponente de esta teoría el pronunciamiento del Tribunal Superior de Justicia de Andalucía de 19-11-2020. La referida Sentencia 3571/20 del TSJA descansa sobre la circunscripción de la calificación jurídica del nulidad o improcedencia a una dimensión procesal. De hecho, viene a diferenciar la decisión empresarial de las medidas a imponer al empresario incumplidor. Sostiene que el despido es un supuesto de resolución contractual y no puede ser calificado como un negocio jurídico abstracto.

La nulidad se refiere al cumplimiento in natura, mientras que la improcedencia se refiere al cumplimiento por equivalente. Ahora bien, ambos son instrumentos de ejecución procesal que han de ser diferenciados de la naturaleza jurídica del despido.

Se potencia así lo que el profesor Beltrán de Heredia ${ }^{21}$ ha dado en llamar la «traducción líquida de la no readmisión" por parte del empresario, observando una línea de continuidad con la Ley de Tribunales Industriales de 1908 y de 1912, el Código de Trabajo de 1926 y, sobre todo, el Decreto de 22 de julio de 1928. De esta forma se constata que la pretensión de facilitar una compensación lo antes posible se ha hecho a costa de que el trabajador renuncie a la «restitutio in integrum» en las extinciones injustificadas. Ahora bien, no podemos olvidar que el marco vigente permite la percepción de indemnización de daños y perjuicios en los despidos con violación de derechos fundamentales (art. 183 LRJS).

Ahora bien, la prestación por equivalencia, no significa —en ningún casoque el empresario tenga reconocido un «derecho de opción» ni el débito indemnizatorio implica el nacimiento de una nueva obligación. Más que de opción en favor del deudor, hay que hablar de transformación de la obligación en obligación indemnizatoria. En consecuencia, no nace una nueva obligación, sino que lo que opera es un cambio en el objeto, sin que ello implique una modificación

\footnotetext{
${ }^{21}$ https://ignasibeltran.com/2017/10/04/despido-fraudulento-y-nulidad-elementos-para-el-debate-ponencia/ (Entrada titulada «Despido fraudulento y nulidad: elementos para el debate, consultada el 11-6-2021 a las 9:50 h.)
} 
de la obligación principal, dado que los sujetos son los mismos y el vínculo jurídico permanece inalterable ${ }^{22}$.

\section{La «prohibición» de despedir}

La Organización Mundial de la Salud elevó el pasado 11 de marzo de 2020 la situación de emergencia de salud pública ocasionada por el COVID-19 a pandemia internacional. La rapidez en la evolución de los hechos, a escala nacional e internacional, requiere la adopción de medidas inmediatas y eficaces para hacer frente a esta coyuntura. Las circunstancias extraordinarias que concurren constituyen, sin duda, una crisis sanitaria sin precedentes y de enorme magnitud tanto por el muy elevado número de ciudadanos afectados como por el extraordinario riesgo para sus derechos.

Con esta introducción se inició la Exposición de Motivos del Real Decreto 463/2020, de 14 de marzo, por el que se declaró el estado de alarma para la gestión de la situación de crisis sanitaria ocasionada por el COVID-19. La declaración inicial comprendió quince días naturales, que fueron posteriormente prorrogados hasta las 00:00 horas del día 12 de abril de 2020, por Real Decreto 476/2020, de 27 de marzo (primera prórroga), hasta las 00:00 horas del día 26 de abril de 2020, por Real Decreto 487/2020, de 10 de abril (segunda prórroga), hasta las 00:00 horas del día 10 de mayo de 2020, por Real Decreto 492/2020, de 24 de abril (tercera prórroga), hasta las 00:00 horas del 24 de mayo de 2020, por Real Decreto 514/2020 de 8 de mayo de 2020 (cuarta prórroga) y hasta las 00:00 horas del 7 de junio de 2020, por Real Decreto 537/2020, de 22 de mayo (quinta prórroga).

La Disposición adicional segunda del inicial Real Decreto 463/2020, de 14 de marzo contempló expresamente la suspensión de plazos procesales y así se decretó lo siguiente:

1. Se suspenden términos y se suspenden e interrumpen los plazos previstos en las leyes procesales para todos los órdenes jurisdiccionales. El cómputo de los plazos se reanudará en el momento en que pierda vigencia el presente real decreto o, en su caso, las prórrogas del mismo.

El apartado 3 de la citada disposición excepcionó en el orden social a los procedimientos de conflicto colectivo y para la tutela de los derechos fundamentales y libertades públicas regulados en la Ley 36/2011, de 10 de octubre, reguladora de la jurisdicción social (LRJS).

${ }^{22}$ Beltrán de Heredia y Onís, P. (1990) El incumplimiento de las obligaciones. Madrid: Edersa. 
Y esta situación de suspensión de plazos procesales se ha mantenido hasta el dictado de la Resolución de 20 de mayo de 2020, del Congreso de los Diputados, por la que se ordena la publicación del Acuerdo de autorización de la prórroga del estado de alarma declarado por el Real Decreto 463/2020, de 14 de marzo, cuyo apartado Noveno ha dispuesto:

Con efectos desde el 4 de junio de 2020, se derogará la disposición adicional segunda del Real Decreto 463/2020, de 14 de marzo, relativa a la suspensión de plazos procesales. Se alzará la suspensión en esa misma fecha.

Coincide así con el art. 9 del Real Decreto 537/2020, de 22 de mayo y con su Disposición derogatoria única que prevé en su primer apartado que:

Con efectos desde el 4 de junio de 2020, quedan derogadas las disposiciones adicionales segunda y cuarta del Real Decreto 463/2020, de 14 de marzo, por el que se declara el estado de alarma para la gestión de la situación de crisis sanitaria ocasionada por el COVID-19.

Por consiguiente, hemos asistido a una inédita situación procesal donde la regla dominante ha sido la suspensión de plazos procesales desde el 14 de marzo de 2020 y ello hasta el 4 de junio de 2020. La actividad judicial realizada en ese intervalo temporal ha sido excepcional y se ha planteado ante un novedoso e ignoto escenario jurídico, donde ha regido una nueva norma en relación al despido, esto es, el artículo 2 del Real Decreto Ley 9/20. Dicho artículo ${ }^{23}$ hace referencia a que las causas de fuerza mayor, económicas, técnicas, organizativa y de producción en las que se amparan las medidas de suspensión de contratos y reducción de jornada previstas en los artículos 22 y 23 del Real Decretoley 8/2020, de 17 de marzo, no se podrán entender como justificativas de la extinción del contrato de trabajo ni del despido ${ }^{24}$.

Sobre la calificación del despido que infrinja el art. 2 RDL 9/2020, establece expresamente la Sentencia del Juzgado de lo Social número 26 de Barcelona de 10-7-2020 que:

Es discutible la calificación que merecen los despidos verificados desconociendo esta previsión legal. La norma nada dice, la exposición de motivos no arroja luz sobre la anterior incógnita, y, evidentemente, no hay doctrina jurisprudencial al respecto.

23 Señalamos que ha sido objeto de numerosas críticas por su deficiente técnica legislativa y dificultades de interpretación.

${ }^{24}$ Sobre este artículo se ha afirmado por la sentencia 283/2020 del Juzgado de lo Social 1 de Barcelona de 15-12 que: «no respeta dicho precepto del Tratado de la Unión Europea (art. 3.3) y de consuno de la Carta Europea de Derechos Fundamentales (art. 16), procede su inaplicación (STJCEE 15-7-1964 Costa-Enel) en tanto en cuanto es merecedora de tutela de derecho de la demanda reconocido en los preceptos del TFUE y CEDF seńalados). 
Deberá ser la Sala de lo Social del Tribunal Supremo la que en unificación de doctrina se pronuncie en el futuro. Este juzgador considera, en tanto en cuanto no exista doctrina jurisprudencial unificada, que los despidos que tengan lugar contrariando el art. 2 del Real Decreto Ley 9/2020 deben ser declarados improcedentes, y no nulos, por las siguientes razones:

1. ${ }^{\circ}$ Por no existir obstáculo que permita predicar la aplicación de la doctrina jurisprudencial consolidada sobre los despidos sin causa.

2. ${ }^{\circ}$ Porque la declaración de nulidad debería reservarse para los casos más graves, expresamente previstos en la ley, especialmente relacionados con los derechos fundamentales.

3. ${ }^{\circ}$ Porque el art. 2 del Real Decreto Ley 9/2020 no introduce una prohibición. Se limita a apuntar que las causas de fuerza mayor o de carácter económico, técnico, organizativo o productivo, derivadas de la crisis por el Covid19, que podrían justificar un expediente de regulación temporal de empleo (ERTE) de los previstos en el Real Decreto Ley 8/2020 «no se podrán entender como justificativas de la extinción del contrato de trabajo ni del despido». Y un despido sin causa es improcedente; pero no nulo.

En refuerzo de lo anterior, se dice por la profesora Viqueira que ${ }^{25}$ :

el legislador podría haber asignado a estos despidos un diferente efecto del que comúnmente se atribuye a los despidos sin causa, pero no lo ha hecho, y, en ausencia de atribución de un efecto específico, tampoco parece que existan elementos que, en el contexto normativo y/o en la Exposición de Motivos, lleven indubitadamente a concluir que estos despidos puedan quedar excluidos del común tratamiento de los despidos sin causa. En efecto, sin desconocer la relevancia que tienen el carácter excepcional de la situación, la especial naturaleza de toda norma de emergencia y la confesada intención del mantenimiento del empleo ya formulada en normas anteriores y en la propia EM del RDL 9/2020, a mi juicio, no existen en el conjunto sistemático en el que la previsión se inscribe razones para desvincular estos despidos del común tratamiento que al despido fraudulento se anuda en la actualidad. Partiendo de esta base, no resulta posible obviar la aplicación de aquel régimen común aplicable a los despidos sin causa y acudir al CC (arts. 6.3; 6.4 y 7.2) para anudar a este despido fraudulento las consecuencias propias de la nulidad del despido.

$\mathrm{Al}$ entender de esta posición, los despidos que infringen el artículo 2 RDL 9/2020 no alcanzan la gravedad necesaria para incluirse entre los despidos con causa prohibida a los que hace expresa referencia el Convenio 158 OIT. Entienden, pues, que ni se vulneran derechos fundamentales ni libertades públicas ni se comprometen derechos con trascendencia constitucional. Así, la Sentencia 551/2020 del Juzgado de lo Social número 2 Girona de 21-12-2020 se expresa en idéntico sentido y dice:

25 Viqueira Pérez, C. (2020): «Acerca del despido que vulnera la pretendida «prohibición de despedir» en Revista de jurisprudencia laboral, BOE, número 9. 
La fuerza mayor y las causas económicas, técnicas, organizativas y de producción en las que se amparan las medidas de suspensión de contratos y reducción de jornada previstas en los artículos 22 y 23 del Real Decreto-ley 8/2020, de 17 de marzo, no se podrán entender como justificativas de la extinción del contrato de trabajo ni del despido", no introduce una prohibición, sino una mera previsión que excluye la posibilidad de considerar justificados $y$, por ende, procedentes, los despidos fundados en las causas anteriores.

Como refuerzo a esta argumentación se alude a que el ET reserva la declaración de nulidad para los casos más graves y entre esas tasadas causas de nulidad no se encuentra el despido fraudulento que, desde 1993, de manera pacífica se entiende incardinado en el terreno de la improcedencia.

\section{Argumentos que sostienen la nulidad de los despidos sin causa}

\subsection{La interpretación del TEDH}

Nos referimos en concreto a la STEDH de 10-7-2012 (K.M.C. contra HUNGRÍA). En este caso ${ }^{26}$ el Tribunal resuelve un supuesto donde la demandante es una funcionaria de un servicio de inspección administrativa. Su empleador la cesó del servicio el 27 de septiembre de 2010 sin dar ninguna razón para el despido, en aplicación de la Ley no. LVIII de 2010 sobre el estatuto de los funcionarios del gobierno, que en ese momento permitía el cese o despido de los funcionarios/as sin necesidad de justificar la causa.

La recurrente, al amparo del art. 6.1 CEDH (Derecho de acceso a un tribunal) denuncia que no pudo combatir de forma efectiva su despido ante un tribunal debido a la falta absoluta de toda justificación de su despido por parte de su empleador.

El Gobierno húngaro había excepcionado la falta de agotamiento de los recursos internos, pues la demandante no accionó por despido. El TEDH rechaza dicha excepción, puesto que la impugnación del despido desconociendo las razones del mismo, es una acción meramente formal sin visos de éxito, cuyo intento, por ello mismo no le es exigible a la demandante.

Una segunda excepción del Gobierno, fue la de estar la demanda manifiestamente infundada, (art. 35.3a) CEDH). La misma fue también rechazada, puesto que al ser la Sra. K.M.C una funcionaria, tenía formalmente el derecho de impugnar su despido ante un tribunal, lo que de por sí supone que el TEDH

\footnotetext{
26 Seguimos el análisis y exposición realizados por Preciado, C. H. (2020) Hablemos de Derechos Humanos. La doctrina del TEDH y su aplicación en España desde los votos particulares del Jueza Paulo Pinto de Alburquerque, Valencia: Tirant lo Blanch.
} 
considere aplicable el art. 6.1 CEDH, conforme a su STEDH 19-4-2007, Caso Vilho Eskelinen y otros c. Finlandia.

El TEDH recuerda que, de conforme a una doctrina consolidada, el artículo 6.1 CEDH puede ser invocado por personas que consideran que han sufrido una injerencia ilícita en el ejercicio de uno de sus derechos (civiles) no han tenido la posibilidad de plantear acción a un tribunal que cumpla con los requisitos del Artículo 6.1 (STEDH 23-6-1981, Caso Le Compte, Van Leuven y De Meyere c. Bélgica).

En el caso concreto, el TEDH observa que la demandante como ex funcionaria del gobierno cesada del servicio tenía, en principio, derecho a impugnar ese despido ante un tribunal. Sin embargo, dado que el empleador no estaba obligado a dar razón alguna para ese despido, el TEDH considera que es inconcebible que el solicitante pueda interponer una acción sobre el fondo, por falta de una posición conocida del empleador demandado. Para el Tribunal, el marco legal aplicable conduce a privar al derecho de acción discutido de todo contenido sustancial.

Las consideraciones anteriores son suficientes para permitir al TEDH concluir que, en litigios relacionados con derechos civiles como el presente, un control judicial tan limitado no puede considerarse como tutela judicial efectiva conforme al Artículo 6.1. Por lo tanto, ha habido una violación del derecho de acceso a un tribunal (ver STEDH 28-6-1990, Caso Obermeier c. Austria, y, a contrario, STEDH 28-9-2011, Caso A. Menarini Diagnostics SRL c. Italia).

En suma, el TEDH considera que la demandante goza, en principio, del derecho a impugnar el despido ante un tribunal. Sin embargo, dado que su empleador - el Estado - no estaba obligado a exponer los motivos del cese, la demandante no tuvo medio alguno de conocer cuál era la posición del empleador, de forma que no ha podido articular una demanda fundada ante los tribunales. El sistema jurídico húngaro supone una privación de facto de todo contenido material al derecho de iniciar un proceso judicial.

El TEDH ha señalado, además, que la falta de conocimiento del trabajador demandante de las razones que fundan su despido imposibilita en sí mismo el ejercicio de un debate contradictorio, descartando cualquier posibilidad de ejercicio de contradicción judicial, violándose el derecho al acceso efectivo a un Tribunal contemplado en el artículo 6.1 del Convenio de Protección de Derechos y Libertades fundamentales, ratificado por España el 10 de octubre de 1979 (STEDH de 20-10-2009, Caso Lombardi Vallaurí contra Italia, fundamentos 54,71 y 72 ).

Algo similar, vendría a ocurrir en nuestro modelo judicial que permite, de facto, la sustitución de la causa explicativa del cese por la puesta a disposición de la indemnización correspondiente al despido improcedente. 


\subsection{La ponderación de los intereses en juego}

La libertad de empresa no implica ningún principio de libertad ad nutum de despido, dada la necesaria concordancia que debe establecerse entre los arts. 35.1 y $38 \mathrm{CE}$ y, sobre todo, el principio de Estado social y democrático de Derecho. Tan es así que la protección del empleo es un principio proclamado por la inmensa mayoría de las normas que intervienen en el ámbito del Derecho del Trabajo. La inserción laboral de las personas satisface las necesidades sociales y económicas de la mayoría de la población y las rentas del trabajo son las que vienen a garantizar en la mayoría de los casos las condiciones de existencia dignas a las que hace referencia el art.7.a).ii) del Pacto Internacional por los Derechos Económicos, Sociales y Culturales. Empleo y dignidad son dos conceptos jurídicos íntimamente relacionados por cuanto que de la existencia del primero depende en no pocas ocasiones la posibilidad del segundo, para el que actúa de presupuesto en múltiples casos.

La Carta Social Europea distingue, con acierto a nuestro entender, entre el derecho a no ser despedido sin justa causa y el derecho a una indemnización o a otra reparación adecuada. De esta manera se distingue entre supuestos que responden a razonamientos diversos. El primero atiende al mantenimiento del empleo como presupuesto del orden social, mientras que el segundo enfoca la vertiente procesal y se centra en el establecimiento de medidas adecuadas de reacción para los casos en que tengan lugar tales despidos, no limitándose a la vertiente patrimonial. De aquí deducimos que la vertiente patrimonial, la traducción económica no es el único ámbito de actuación del Derecho del Trabajo.

El derecho a no ser despedido sin justa causa se integraría así en la parte esencial del contenido del derecho al trabajo, e incide en la causa, que se contempla legalmente (art. 54 y art. 52.c) y $51.1 \mathrm{ET}$ ); en la forma, pues la decisión al deber ser exteriorizada por escrito, para información y conocimiento del trabajador (art. 53.1 y $55 \mathrm{ET}$ ), y para que pueda ejercitar su derecho de defensa; posibilitándose así el control judicial posterior y conectando con el contenido esencial del artículo $24 \mathrm{CE}$.

En efecto, el TC sostiene en su importante ATC 43/2014, de 12-2 que:

el ámbito de las relaciones de trabajo a que se refiere el art. $35 \mathrm{CE}$ constituye una esfera "cuya configuración se defiere al legislador» (STC 20/1994, de 27 de enero [RTC 1994, 20], FJ 2), con la consecuencia de que dentro de dicha configuración legal queda incluida la determinación de las técnicas y alcance de la reacción frente a la extinción del contrato de trabajo. Así, en algunos pronunciamientos relativos a la relación laboral se ha afirmado que «corresponde al legislador determinar las justas causas de extinción del contrato, así como fijar sus efectos» [ATC 57/1985, de 24 de enero, FJ 4; y ATC 429/1983, de 28-9 (RTC 1983, 429 AUTO), FJ 2]. 


\subsection{La naturaleza jurídica del artículo $35 \mathrm{CE}$}

El artículo $35 \mathrm{CE}$ es un auténtico derecho constitucional, que no necesita de desarrollo legal para poder ser objeto de tutela y que puede invocarse y exigirse ante los Tribunales. Cierto es que no se encuentra en la Sección 1. a del Cap. II del Título I ${ }^{27}$, sino en la Sección 2. ${ }^{a}$, pero también lo es que no por eso deja de ser un derecho fundamental.

Otro argumento para sostener la nulidad del despido sin causa es el art. 6.3 $\mathrm{CC}$, puesto que es contrario a una norma de derecho fundamental prohibitiva, ya que el art. 35.1 CE prohíbe el despido sin justa causa, sin que pueda considerarse que las causas de nulidad están tasadas en el art. 108 y en el arts. 53.3 o 55.5 ET, puesto que, si bien es cierto que tal es la doctrina del TS, no es menos cierto que el TC ha considerado que el Título Preliminar del CC es de aplicación a todo el ordenamiento $^{28}$, incluidos los derechos fundamentales, también el del art. 35.1 CE- y que por tanto, los actos contrarios a las normas de derechos fundamentales —que son normas imperativas, de ius cogens-, deben tener como consecuencia la nulidad (art. 6.3 CE), salvo que la norma específica (ET o LRJS) establezca un efecto distinto para el caso de contravención, que no es el caso.

Asimismo, es relevante tener presente que no es cierto que nuestro ordenamiento únicamente prevea la nulidad para los casos de incumplimientos de fondo más graves. De hecho, se prevé expresamente la nulidad (ex art. 124 LRJS) para los despidos colectivos en fraude de ley - por ejemplo, los irregulares y de hecho- . Es decir, que lo que se permite por razón numérica no parece razonable negarlo por razón «jurídica».

Pues bien, en refuerzo de lo anterior, debemos también tener en consideración que por un lado, la Comisión de Expertos en la Aplicación de Convenios y Recomendaciones de la OIT (CEACR) ha declarado que la necesidad de basar la terminación del empleo en una justa causa es la piedra angular de las disposiciones del Convenio de la OIT antes mencionadas, ya que «elimina la posibilidad de que el empleador termine unilateralmente una relación laboral de duración indeterminada mediante un período de preaviso o compensación en lugar de la misma ${ }^{29}$, y por otro, el Comité de Derechos Económicos, Sociales y Culturales de la ONU (CDESC) en su Observación General número 18 señaló que las vulneraciones del derecho al trabajo pueden ocurrir a través de conductas

\footnotetext{
27 En consecuencia, no opera ni la reserva de Ley Orgánica ni el recurso de amparo respecto del mismo (ex art. $53 \mathrm{CE})$.

28 SSTC 120/1983, de 15-12, 41/1984, de 21-3 88/1985, de 19-7, ATC 171/1985, de 6-3. Por ejemplo, en la STC 37/1987 de 27-3, el TC sostiene, respecto del fraude de ley (art. 6.4 CC), que: «el citado precepto, como la mayor parte de los que integran el título preliminar, es aplicable a todo el ordenamiento, y sólo por tradición histórica, sin duda, respetable, conserva en el CC su encaje normativo".

${ }^{29}$ CEACR (1995), Estudio general - Protección contra el despido injustificado.
} 
omisivas, por ejemplo, cuando los Estados parte no regulan las actividades de las personas o grupos para evitar que impidan el derecho de otros a trabajar. Por lo tanto, el CDESC consideró que

las violaciones de las obligaciones de proteger derivan del incumplimiento por parte de los Estados parte de su obligación de adoptar todas las medidas necesarias para proteger a las personas bajo su jurisdicción de las violaciones del derecho al trabajo por parte de terceros. Se incluyen omisiones como (...) la falta de protección de los trabajadores contra el despido ilegal ${ }^{30}$.

La aparición de algún pronunciamiento judicial que se aparta de la doctrina mayoritaria es otro refuerzo para los argumentos esgrimidos. Así podemos indicar la sentencia 93/2020 de 6-7-2020 dictada por el Juzgado de lo Social número 3 de Sabadell, que razona:

En definitiva, se considera que, en realidad, la extinción de contrato de la actora se produjo como consecuencia de la situación derivada de la declaración del Estado de Alarma y la existencia de circunstancias que habilitaban a la empresa para adoptar las medidas previstas en $\mathrm{RD}$ 8/2020 por lo que, al extinguir la relación laboral de la actora no solo aduce una causa que no justifica la extinción, según los artículos 22 y 23 de RDL 8/2020 y artículo 2 del RDL 9/2020, sino que supone un incumplimiento de las disposiciones legales adoptadas por el legislador con la finalidad de evitar la destrucción de empleo, finalidad que se refleja en Exposición de Motivos (III) del RD 8/2020, en que sostiene que las medidas del Capítulo III del RD-Ley 8/20 están orientadas a evitar despidos y a conservar el empleo, y esa finalidad habrá de predominar en la hermenéutica que regula los despidos en el ámbito excepcional del COVID-19, siendo esta finalidad la que justifica la redacción del art. 2 RD-Ley 9/2020.

Siendo así, consideramos de aplicación el art. 6.3 del Código Civil por cuanto la extinción del contrato de trabajo de la actora constituye un acto contrario a norma imperativa además de constituir un fraude de ley, art. 6.4 del Código Civil, pues la empresa se ampara en causa inexistente para conseguir un resultado prohibido por el ordenamiento jurídico, esto es, la extinción de la relación laboral a fecha 28.3.2020 cuando las normas vigentes proscriben la destrucción de empleo derivada de la situación excepcional del Estado de alarma derivado de COVID-19. En consecuencia, procede declarar la nulidad del despido notificado a la actora con efectos de 28.3.2020, con las consecuencias previstas en artículo 55.6 ET.

Y más recientemente destaca de un lado la Sentencia 119/2021 del Tribunal Superior de Justicia del País Vasco de 26-1-202131 que razona así:

${ }^{30}$ Observación general N. ${ }^{o} 18$ sobre el derecho al trabajo, Comité de Derechos Económicos, Sociales y Culturales de las Naciones Unidas (E/C.12/GC/18), adoptada el 24 de noviembre de 2005, en el párrafo 35. Véase también el párrafo 11 de la observación general en el que se hace referencia explícita al artículo 4 del Convenio núm. 158.

31 Los criterios han sido reproducidos en sentencias posteriores del mismo Tribunal, a saber la número 331/21 de 23-2-2021 y la número 772/2021 de 4-5-2021. 
Sin embargo, lo cierto es que la cuestión merece otra reflexión. Así, es claro que la norma referida —artículo 2 del RDL 9/2020—, en relación con los artículos 22 y 23 del RDL 8/2020 revela que el legislador ha querido dar total preferencia a los mecanismos de flexibilidad interna - expedientes de suspensión de contratos y reducción de jornada - frente a los de flexibilidad externa o extinción de los contratos de trabajo. Para ello ha tomado las medidas ya conocidas de exoneración de cotizaciones a la Seguridad Social, mantenimiento del empleo, y esta "prohibición" de despedir por causas económicas, técnicas, organizativas y de producción.

(...)

Es claro también que la empresa, al invocar las causas económicas indicadas, lo hizo para esquivar o evitar la aplicación de la norma que la parte demandante denuncia, esto es, esa "prohibición» de despedir del artículo 2 del RDL 9/2020, en los términos antedichos. Lo que supone un auténtico fraude de ley del art. 6.4 del Código Civil, habida cuenta de esa nítida voluntad del legislador de priorizar el mantenimiento del empleo a través de la utilización de las medidas de flexibilidad interna que se favorecen, frente a la extinción de los contratos.

(...) Es consciente la Sala de la existencia de un importante debate doctrinal y judicial en torno a esta cuestión. La Sala entiende que, aunque el legislador no haya determinado la calificación que han de merecer estos despidos que vulneran el artículo 2 del RDL 9/2020, nuestra consideración de tratarse de despidos en fraude de ley, vinculada a la necesaria efectividad del derecho al trabajo del artículo $35 \mathrm{CE}$ - en el que se inserta el derecho a no ser despedido sin justa causa- y a la clara voluntad legislativa de impedir los despidos por causas económicas, técnicas, organizativas y productivas en esta crisis derivada de la COVID-19, nos llevan a declarar la nulidad del despido.

Y de otro lado, la sentencia 772/2021 del Tribunal Superior de Justicia de Asturias de 30-3-2021, que dispone:

Este marco excepcional y extraordinario, en el que se considera primordial evitar la extinción de los contratos de trabajo y se configuran mecanismos para su pervivencia, debe informar la interpretación del art. 2 del Real Decreto-Ley 9/2020. El cumplimiento de la finalidad pretendida expresamente por la normativa en la cual se integra como medida esencial, criterio interpretativo fundamental a tenor del art. 3.1 del Código Civil y determinante de la utilidad de la norma para afrontar la crisis, hace que la nulidad del despido sea la consecuencia natural.

El supuesto ahora sometido a examen ejemplifica bien que la improcedencia del despido constituye una solución que frustraría las finalidades no ya del art. 2 del Real Decreto-Ley 9/2020, sino en general de dicho marco normativo, excepcional y extraordinario, dedicado a proteger el empleo. En las contrataciones temporales, tan frecuentes en Espańa, la calificación de improcedencia del despido, al decidir la empresa la ruptura de la relación laboral, se resuelve con el abono por el empresario de indemnizaciones de escasa cuantía, que no desincentivan la extinción de los contratos de trabajo. El legislador no establece de forma expresa la nulidad de los despidos que vulneren el mandato derivado del art. 2 del Real Decreto-Ley 9/2020. No resulta imprescindible, pues la nulidad es la consecuencia congruente y ajustada con la normativa de la que forma parte. 
En idéntico sentido podemos encontrar estos otros pronunciamientos jurisprudenciales $^{32}$ :

- Sentencia 180/2020 del Juzgado de lo Social número 29 de Barcelona de 28-7.

- Sentencias 305/2020 y 338/2020 del Juzgado de lo Social número 6 de Oviedo de 22-10 y de 10-11-2020.

- Sentencia 68/2021 de 26-2-2021 del Juzgado de lo Social número 16 de Barcelona.

Por último, debemos de destacar que la publicación en el BOE de 11-62021 del instrumento de ratificación de la Carta Social Europea, puede conllevar la adaptación de algún criterio jurisprudencial, por cuanto que algunos Tribunales habían hecho expresa referencia a esta circunstancia y así la Sentencia 277/2021 del Tribunal Superior de Justicia de Madrid establecía en su sentencia de 17-3-2021 que:

Sin embargo [no] cabe aplicar, como se hace en la sentencia de instancia, el artículo 24 de la Carta Social Europea revisada, puesto que se trata de un tratado internacional que no ha sido ratificado todavía por España y no está publicado en el Boletín Oficial del Estado. Por tanto, la interpretación que pueda hacerse de dicho precepto por el Comité de Derechos Sociales del Consejo de Europa no es relevante para este litigio, porque el propio precepto no es aplicable. Cuando finalice el proceso de ratificación de la Carta Social revisada por Espańa y el nuevo tratado sea objeto de publicación oficial podrá plantearse la naturaleza vinculante del «Derecho derivado" resultante del tratado, esto es, de las resoluciones de órganos del Consejo de Europa como el Comité de Derechos Sociales.

Nos remitimos al respecto a lo expresado por ejemplo en sentencia de 18-52016 de la Sala de lo Social del Tribunal Superior de Justicia de Castilla y León en el recurso 361/2016:

En cuanto a la Carta Social Europea hay que tener en cuenta que la versión aplicable en España es la hecha en Turín de 18 de octubre de 1961, que es la firmada por España el 27 de abril de 1978, ratificada el 6 de mayo de 1980 y publicada en el BOE de 26 de junio de 1980, con la excepción del artículo 8 (4) (b), que fue denunciado en 1991 (BOE 10 de mayo de 1991). No es aplicable la carta revisada en 1996, que ha sido firmada (el 23 de octubre de 2000), pero no ratificada por España, ni, obviamente, ha sido objeto de publicación oficial. También hay

32 Hemos de señalar que, en cualquier caso, son más numerosas las sentencias que mantienen la calificación de improcedencia, entre otras: Sentencia del Tribunal Superior de Justicia de Castilla y León/Valladolid de 26-3-2021 (rec. 300/2021), Sentencia del Tribunal Superior de Justicia de Galicia de 11-3-2021 (rec. 150/2021), Sentencia del Tribunal Superior de Justicia de Madrid de 2-22021 (rec. 18/2021) 
que tener en cuenta que España ha firmado ( 5 de mayo de 1988), ratificado (24 de enero de 2000) y publicado en el BOE (25 de abril de 2000) el Protocolo Adicional de 5 de mayo de 1988. También ha firmado ( 2 de octubre de 1991) y ratificado ( 24 de enero de 2000) el Protocolo Adicional de 21 de octubre de1991. No ha firmado ni ratificado el Protocolo Adicional de 9 de noviembre de 1995 sobre el procedimiento de reclamaciones colectivas, el cual, en la medida en que pueda entenderse que atribuye competencias estatales a un organismo internacional, requeriría probablemente de Ley Orgánica para ello conforme al artículo 93 de la Constitución. Debe añadirse que el procedimiento del control del cumplimiento de la Carta Social Europea aplicable a España, resultado del texto original con el protocolo adicional de 21 de octubre de 1991, no confiere al Comité de Expertos Independientes del artículo 25 la competencia para dictar resoluciones interpretativas como consecuencia de sus conclusiones sobre los informes anuales que puedan considerarse vinculantes para los Estados miembros (artículo 24), aun cuando dichas conclusiones sean hechas públicas. Solamente si dichas conclusiones llegan a ser aprobadas como recomendaciones por el voto favorable de 2/3 del Comité de Ministros, tras el análisis y propuesta realizado por el Comité Gubernamental, tendrán el valor propio de las mismas, que el tratado no especifica pero que tampoco puede considerarse estrictamente vinculante. A título de ejemplo, el valor jurídico de este mecanismo de revisión, desde el punto de vista del Derecho interno español, es similar al que tienen los informes del Órgano de Examen de las Políticas Comerciales (OEPC) de la Organización Mundial del Comercio u otros actos derivados de procedimientos regulados en dicho tratado, puesto que, al igual que ocurre con la Carta Social Europea, la ratificación del Acuerdo por el que se establece la Organización Mundial del Comercio y del Acuerdo sobre Contratación Pública, hechos en Marrakech el 15 de abril de 1994, se hizo previa autorización de las Cortes por el procedimiento del artículo 94.1 de la CE y no por Ley Orgánica amparada en el artículo 93 de la misma. Por tanto los órganos judiciales nacionales deben llevar a cabo la necesaria labor interpretativa de los textos de la Carta Social Europea, al igual que los de los demás convenios internacionales, aplicando para ello los criterios establecidos en los artículos 31 a33 del Convenio de Viena sobre el Derecho de los Tratados y utilizando solamente con valor orientativo, entre los criterios aplicables, las eventuales interpretaciones del tratado que pudieran haber dado a su contenido órganos internos que no tengan atribuidas competencias del Estado por la vía del artículo 93 de la Constitución». La única matización que cabe hacer a lo expuesto en esa sentencia del año 2016 es que hace unas semanas España ha firmado el Protocolo Adicional de 9 de noviembre de 1995 sobre el procedimiento de reclamaciones colectivas, que está pendiente de ratificación y publicación. En base al mismo las resoluciones del Comité de Derechos Sociales podrán entenderse vinculantes en España como «Derecho derivado", al menos si se llega a cumplir el principio de atribución, esto es, si esa competencia hubiera sido atribuida a dicho Comité al amparo del artículo 93 de la CE, cuestión que ahora es totalmente hipotética y no resulta relevante para el caso. Lo que no cabe es aplicar a este caso un tratado todavía no ratificado y el criterio de un órgano internacional expresado en base a un procedimiento contenido en otro tratado no ratificado todavía. 


\section{Conclusiones}

Nuestro modelo de relaciones laborales no ha mantenido una tendencia constante en la calificación jurídica de los denominados despidos sin causa, que han oscilado entre las calificaciones de nulidad e improcedencia.

Esta falta de rotundidad ha generado - y sigue generando- el que existan posiciones no solo doctrinales sino también jurisprudenciales abiertamente enfrentadas.

De dicha situación se produce un escenario de inseguridad jurídica, que no favorece ni a empleadores ni a trabajadores, por cuanto no es posible establecer previsiones con conclusiones ciertas ante determinadas conductas.

Mayoritariamente, se viene considerando que el despido sin causa dejó de poder ser calificado nulo desde 1993, y ello a raíz del cambio legislativo operado que tasaba las causas de nulidad, excluyendo cualquier otra que no estuviera expresamente contemplada.

Sin embargo, hay quien mantiene que existen otros argumentos que conducen a la calificación de nulidad de los despidos operados sin causa: la transgresión de la buena fe en las relaciones laborales, las normas internacionales o la consideración del derecho al trabajo como derecho fundamental.

No parece razonable que más de cuarenta años después de promulgarse la CE no exista una posición consensuada sobre las implicaciones jurídicas del artículo $35 \mathrm{CE}$ en materia de despido. Y sorprende que la naturaleza de este derecho constitucional como derecho fundamental sea un elemento soslayado en la posición jurisprudencial mayoritaria. De hecho, se pone en cuestión la eficacia erga omnes de los derechos fundamentales específicamente laborales, así como de los derechos inespecíficos en la relación laboral.

Estamos en un entorno normativo cambiante -incluso trepidante, en el ámbito laboral - y donde la pandemia del COVID-19 ha "traído» consigo una verdadera reforma integral y exprés de múltiples instituciones laborales: teletrabajo, permiso retribuido, las suspensiones temporales de empleo, etc. Esta reforma también ha afectado al despido, generándose un nuevo escenario normativo que destaca por su falta de rigor técnico. A nadie se le escapa que una norma tan breve (el art. 2 RD 9/2020) no ha sido eficaz cuando está generando multitud de interpretaciones y sentencias contradictorias ante supuestos análogos.

Se evidencia que la falta de normas infraconstitucionales que regulan la relación entre derechos fundamentales inespecíficos y contrato de trabajo suscita una indeseada situación donde los juzgados y tribunales vienen asumiendo una función y responsabilidad "cuasi legislativa» que obviamente no les corresponde. 
Tal anomia implica que sea la jurisprudencia quien interprete y aplique los preceptos constitucionales al supuesto concreto.

La causalidad encuentra su fundamento en la función tuitiva del Derecho del Trabajo, que protege a la parte débil, el trabajador frente a la fuerte, el empleador. Es una institución central en nuestro ordenamiento jurídico-laboral que viene a objetivar las decisiones muy relevantes de la relación laboral.

Tradicionalmente se había considerado el desistimiento como una figura genuinamente civil, cuya utilización en el Derecho del Trabajo por parte del empresario era excepcional a consecuencia, precisamente, de la configuración del despido como un verdadero despido causal.

Ahora bien, el despido sin causa viene más bien a compartir los rasgos del desistimiento antes que los del despido causal, por cuanto que se aparta del elemento central: la existencia y la manifestación de la causa motivadora.

Nuestro ordenamiento prevé la calificación jurídica de nulidad no solo para comportamientos que vulneren los derechos fundamentales con mayor grado de protección, sino que también incluye otros supuestos, por ejemplo, en los despidos colectivos.

No parece razonable que la calificación jurídica de un despido donde se omita la causa o donde se ofrezca una falsa reciba el mismo tratamiento jurídico que otro donde la parte empleadora intente al menos adaptar su comportamiento a las previsiones legales, tanto materiales como formales. Tan es así que se vendría a incentivar el incumplimiento de los mismos por cuanto que las consecuencias del incumplimiento apenas se diferenciarían. Puede generarse una situación de incentivos negativa, donde se tienda a la normalización de la mala fe en el ámbito laboral.

Es importante que el ordenamiento jurídico, ante una conducta antijurídica, prevea un mecanismo apto para reequilibrar la tradicional desigualdad de las partes en el contrato de trabajo. Resulta llamativo que en caso de despido improcedente sea el incumplidor - la parte empleadora- quien disponga, por regla general, del derecho de opción a la hora de ejecutar la condena. Aún más extraño sería que quien opera con mala fe también pudiera optar por cómo cumplir una condena.

Por todo lo expuesto, nos atrevemos a proponer una solución intermedia e integradora de las posturas doctrinales y jurisprudenciales analizadas vendría a ser que la calificación jurídica del despido fuera la improcedencia, pero, en casos de constatación de mala fe, con reversión del derecho de opción a favor de la parte trabajadora, a quien correspondería optar — como víctima del incumplimiento- entre la readmisión y la indemnización.

De esta manera, se evitaría además la traducción económica con tendencia al abaratamiento de aquellos despidos donde operasen los incumplimientos que 
se dan en los despidos sin causa, de mayor entidad, en todo caso, que en los despidos con causa y comunicación de la misma.

\section{Bibliografía}

Aparicio, Rebeca Karina y Ubillús, Rolando Enrique (2014). «El despido ad nutum como medida inconstitucional de reestructuración laboral», Revista chilena de Derecho del Trabajo y de la Seguridad Social, vol. 5, número 10.

Baylos, Antonio y Pérez, Joaquin (2009). El despido o la violencia del poder privado. Madrid: Trotta.

Bayón Chacón, Gaspar (1969). El despido, concepto y clases» en AA.VV.: Dieciséis lecciones sobre causas de despido. Madrid: Universidad de Madrid. Facultad de Derecho. Sección de Publicaciones e Intercambio.

Beltrán, Ignasi (2013). Principio de economía procesal y limitación de la responsabilidad contractual por despido injustificado. La responsabilidad civil por daños en las relaciones laborales XXIII Congreso Nacional de DTSS, Madrid: Ediciones Cinca, 2013.

Beltrán de Heredia y Onís, Pablo (1990). El incumplimiento de las obligaciones. Madrid: Edersa.

Cano y Galán, Yolanda (2000). El despido libre y sus limites en el derecho norteamericano, Madrid: Consejo Económico y Social.

CEACR (1995). Estudio general - Protección contra el despido injustificado.

Del ReY, Salvador (1995). «Derechos fundamentales de la persona y contrato de trabajo: notas para una teoría general», Relaciones Laborales: revista crítica de teoría y práctica, número 186 , tomo I.

Falguera, Miguel Ángel (2016). El control judicial del despido colectivo, Albacete: Bomarzo.

Ferrajoli, Luigi (2019). Derechos y garantías, Madrid: Trotta.

Gallego, Fermin y Marín, José (2013). Costes del despido improcedente en la doctrina judicial, Albacete: Bomarzo.

García Viña, Jordi (2000). El principio general de la buena fe en cl contrato de trabajo, Tesis Doctoral, Barcelona: Universidad de Barcelona.

Gómez Abelleria, Franciso Javier (2009). La causalidad del despido disciplinario, Cizur Menor: Civitas-Thomson Reuters.

Lahera, Jesús (2009). «Las paradojas del despido libre pagado (Sentencia del Tribunal Supremo de 22 de enero de 2008, recurso 1689/2007)», en Relaciones Laborales, número 2.

Luján Alcaraz, José (2003). «¿Despido improcedente o desistimiento?», Aranzadi Social n. 3 .

Montoya Melgar, Alfredo (1978). "La estabilidad en el empleo en el Derecho del Trabajo", Revista de Politica Social, n. ${ }^{\circ} 118$.

Montoya Melgar, Alfredo (2006). Derecho del Trabajo, Madrid: Tecnos.

Moreno García, Antonio (1993). «Buena fe y derechos fundamentales en la jurisprudencia del Tribunal Constitucional», en Revista Española de Derecho Constitucional, número 38.

Pérez-Beneyto, José Joaquín (2004). «Despido improcedente (I): supuestos y efectos. Especial referencia a los salarios de tramitación. El despido: análisis y aplicación práctica» en AA.VV.: El despido: análisis y aplicación práctica, Madrid: Tecnos. 
Preciado, Carlos Hugo (2016). Interpretación de los derechos humanos y los derechos fundamentales, Cizur Menor: Aranzadi.

Preciado, Carlos Hugo (2020). Hablemos de Derechos Humanos. La doctrina del TEDHy su aplicación en España desde los votos particulares del Jueza Paulo Pinto de Alburquerque, Valencia: Tirant lo Blanch.

Rodríguez SAÑudo, Fermín (1990). "La transgresión de la buena fe contractual como causa de despido", en Cuestiones Actuales de Derecho del Trabajo. Estudios ofrecidos por los catedráticos españoles de Derecho del Trabajo al profesor Manuel Alonso Olea, Madrid: Ministerio de Trabajo y Seguridad Social.

Rubio de Medina, M. ${ }^{a}$ Dolores (2000). El despido disciplinario, Barcelona: Editorial Bosch.

Toledo, Albert (2008). El despido sin causa del trabajador en situación de incapacidad temporal, A Cizur Menor: Aranzadi.

Viqueira Pérez, Carmen (2020). "Acerca del despido que vulnera la pretendida "prohibición de despedir» en Revista de jurisprudencia laboral, BOE, número 9.

Zanonni, Eduardo A. (1982). El daño en la responsabilidad civil, Buenos Aires: Astrea. 